\title{
3-Phenyl/Pyridinyl Derivatives of Trans-2-(aryl/heteryl)vinyl-3H-quinazolin-4-ones: Synthesis and Fluorescent Properties
}

\author{
Emiliya V. Nosova ${ }^{1}$, Tatyana V. Stupina ${ }^{1}$, Galina N. Lipunova ${ }^{2}$, \\ Marina S. Valova ${ }^{2}$, Pavel A. Slepukhin ${ }^{2}$, Valery N. Charushin ${ }^{1,2}$ \\ ${ }^{1}$ Department of Organic Chemistry, Chemical Technology Institute, Urals Federal University, \\ Ekaterinburg, Russia \\ ${ }^{2}$ Postovsky Institute of Organic Synthesis, Ural Branch of the Russian Academy of Sciences, Ekaterinburg, Russia \\ Email: emily74@rambler.ru, lipunova@ios.uran.ru
}

Received November 22, 2011; revised December 30, 2011; accepted January 7, 2012

\begin{abstract}
Novel 3-phenyl/pyridinyl-trans-2-(aryl/heteryl)vinyl-3H-quinazolin-4-ones 3a,b, 4a, 5a, 7a and their 6,7-difluoro derivatives $\mathbf{3 c}, \mathbf{d}, \mathbf{4 b}, \mathbf{5 b}, \mathbf{7 b}$ have been obtained by condensation of the correspondent 2-methylquinazolin-4-ones $\mathbf{1}, \mathbf{6}$ with aromatic (heterocyclic) aldehydes in the presence of $\mathrm{ZnCl}_{2}$ (AcONa) or by the reaction of 2-methyl-3,1-benzoxazin-4ones 2 with the Shiff bases. Effects of aryl(heteryl) substituents on photophysical properties of (aryl/heteryl) quinazolinylethenes have been studied.
\end{abstract}

Keywords: Styryl Benzazines; Fluorinated Quinazolin-4-ones; UV and FL Spectra; X-Ray; Trans-cis-isomerisation; 2-Methylquinazolinones; 2-Methyl-3,1-benzoxazinones

\section{Introduction}

The creation of luminescent molecules that contain the styryl moiety is an active field of research in organic chemistry $[1,2]$. Substitution of the phenyl fragment in stilbenes with a heterocyclic unit (for instance, pyridine) has been established to give a significant effect on their photophysical and photochemical properties, because of involvement of the $\left(n \pi^{*}\right)$ electronic state [3]. It is known that fluorescent properties of conjugated systems can be changed by varying the structure of stilbenes and their analogues, and this approach proved to be useful to develop new optical materials and fluorescent markers for studying biomolecules [2]. In particular, fluorescent indicators can be used in hormonal therapy of breast cancer to monitor the distribution of estrogen receptors in tumor cells [4]. Photophysical properties of some styryl substituted azines have been intensively studied, and the data on luminescent properties of trans-2-styrylpyridazin3(2H)-ones [5], 3-(2-arylvinyl)-pyridazines [6] and (arylvinyl) pyrimidines [7] are available. As for benzodiazines, photophysical behavior of 2-styryl-3H-quinazolin4-ones, aza-analogues of styrylquinolines, have been reported [8], and these compounds can be regarded as candidates for OLED (organic light emitted diodes).

Taking into account the growing interest to modification the core of conjugated molecules in order to estimate structural effects on the LED properties [9], we wish to report the synthesis and photophysical behavior study of 3-phenyl-trans-2-styryl-substituted $3 H$-quinazolin-4-ones and their analogs in current work. Considering an opportunity to improve the electronic conductivity by incorporating of fluorine atoms into styryl derivatives $\mathrm{Ph}-\mathrm{CH}=$ $\mathrm{CH}-\mathrm{C}_{6} \mathrm{H}_{4}-\mathrm{CH}=\mathrm{CH}-\mathrm{Ph}[10,11]$, a number of novel fluorinated 3-phenyl-trans-2-styryl-3 $H$-quinazolin-4-ones have been obtained.

\section{Results and Discussion}

Trans-2-(Arylvinyl)-3H-3-phenylquinazolin-4-ones 3b,d have been synthesized by condensation of 2-methylquinazolinones $\mathbf{1 a}, \mathbf{b}$ with $p$-nitrobenzaldehyde on heating in tetrahydrofuran in the presence of $\mathrm{ZnCl}_{2}$ and acetic anhydride for 6 hours in 59\% - 71\% yields (Scheme 1). The synthesis of 3a,c has been performed by refluxing 2methyl-3,1-benzoxazinones 2a,b with the Shiff base $4-\mathrm{MeOC}_{6} \mathrm{H}_{4}-\mathrm{CH}=\mathrm{N}-\mathrm{Ph}$ and sodium acetate in acetic acid for 6 hours in 50\% - 75\% yields (Scheme 1) [12]. The $\mathrm{CH}=\mathrm{CH}$ resonance signals in ${ }^{1} \mathrm{H}$ NMR spectra of 3a-d proved to appear as doublets at $6.11-6.49$ and 7.86 $7.96 \mathrm{ppm}$ with ${ }^{3} \mathrm{~J} 15.4-15.6 \mathrm{~Hz}$, thus indicating at transconfiguration of this fragment.

$\mathrm{X}$-Ray crystallography analysis has been performed to establish the structure of quinazolinone $\mathbf{3 b}$. Summary on 


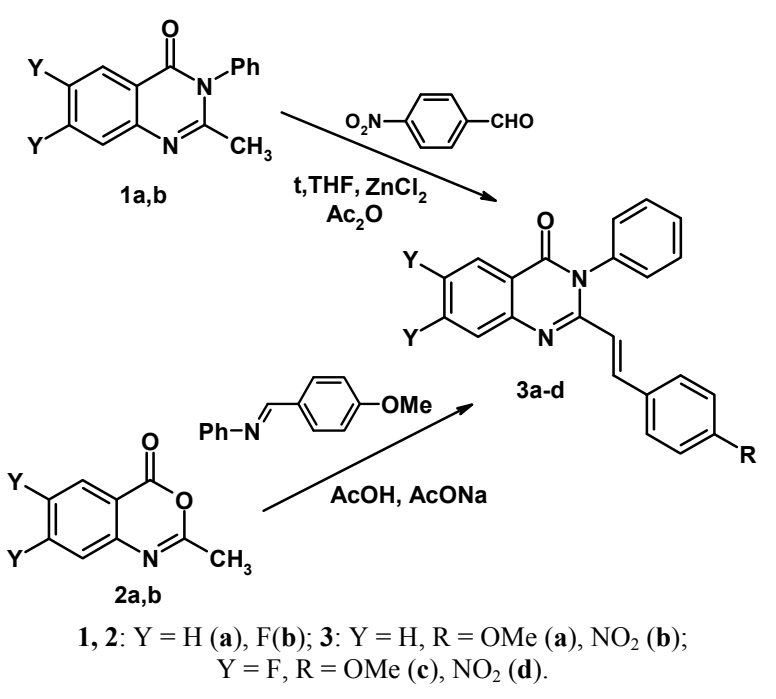

Scheme 1. Synthesis of 2-styryl-3-phenyl-3H-quinazolin-4ones 3 .

the data collection and refinement parameters are presented in Table 1, while chemical bond distances and angles are given in Table 2 . The molecular structure of $\mathbf{3 b}$, based on the X-ray crystallography data, is shown in Figure 1. According to the X-ray data obtained, the compound is crystallized in the chiral space group of the orthorhombic crystal system. The molecule has trans-configuration of the alkenyl fragment. Nitrophenyl and quinazolinyl parts are located approximately in the plane of $\mathrm{C}=\mathrm{C}$ bond, and $\mathrm{C}-\mathrm{C}$ bond distances for this fragment are typical for conjugated systems (see Table 2). The plane of the phenyl substituent in quinazoline forms a dihedral angle $74.3^{\circ}$ relative to the heterocyclic ring. In the molecular packing short contacts $\mathrm{C}=\mathrm{O} \ldots \mathrm{H}-\mathrm{C}_{\mathrm{Ar}}$ type $(\mathrm{O}(3) \ldots$ $\mathrm{H}(21 \mathrm{~A}) 2.448 \AA, \mathrm{O}(3) \ldots \mathrm{C}(21) 3.167 \AA$, symm. op. $1 / 2-$ $\mathrm{x}, 2-\mathrm{y},-1 / 2+\mathrm{z})$ are observed. Summary on the data collection and refinement parameters are presented in Table 1, while chemical bond distances and angles are given in Table 2. The molecular structure of $\mathbf{3 b}$, based on the X-ray crystallography data, is shown in Figure 1.

We have fulfilled the structural modification of compounds 3 by incorporating of the second heterocyclic unit instead of the aryl substituent. It is known that replacement of the aryl fragment with the $\pi$-excessive thiophene ring leads to a large red-shift in both absorbtion and emission spectra [13-15]. Thiophene has a lower resonance energy compared to that of benzene, and a better coplanar conformation relative to polyenes $[16,17]$. On the other hand, some new materials have recently been developed, in which their molecules can absorb two photons simultaneously, thus leading to two-photons excited fluorescence (TPEF). Such molecules are widely used for two-photons excited up-converted laser, two-photons fluorescence microscopy, three-dimensional optical memory, and photodynamic therapy. The systems with strong TPEF are $\pi$-conjugated molecules based on polyvinyl or styryl derivatives. Compounds bearing the thiophene ring as electron-donating fragment may have even better TPEF characteristics [18]. In order to compare eff-

Table 1. X-ray crystallography data for $3 \mathrm{~b}$.

\begin{tabular}{|c|c|}
\hline Empirical formula & $\mathrm{C}_{22} \mathrm{H}_{15} \mathrm{~N}_{3} \mathrm{O}_{3}$ \\
\hline Formula weight & $369.38 \mathrm{Da}$ \\
\hline Temperature & $295(2) \mathrm{K}$ \\
\hline Crystal size & $0.25 \times 0.20 \times 0.15 \mathrm{~mm}$ \\
\hline Crystal system & Orthorhombic \\
\hline Space group & $\mathrm{P} 2{ }_{1} 2_{1} 2_{1}$ \\
\hline Unit cell dimensions & $\begin{array}{l}\mathrm{a}=6.7654(2) \AA, \alpha=90^{\circ} \\
\mathrm{b}=15.5930(5), \beta=90^{\circ} \\
\mathrm{c}=17.3470(5), \quad \gamma=90^{\circ}\end{array}$ \\
\hline Volume & $1829.99(10) \AA^{3}$ \\
\hline Z & 4 \\
\hline Density (calculated) & $1.341 \mathrm{~g} \cdot \mathrm{cm}^{-3}$ \\
\hline Absorption coefficient & $0.092 \mathrm{~mm}^{-1}$ \\
\hline $\mathrm{F}(000)$ & 768 \\
\hline Theta range for data collection & $2.86^{\circ}$ to $28.28^{\circ}$ \\
\hline Completeness to theta $=28.28^{0}$ & $99.5 \%$ \\
\hline Index ranges & $\begin{array}{l}-5 \leq \mathrm{h} \leq 9,-17 \leq \mathrm{k} \leq 20 \\
-23 \leq 1 \leq 23\end{array}$ \\
\hline Reflecions collected & 8769 \\
\hline Independent reflections & $2582\left[\mathrm{R}_{\text {int }}=0.0162\right]$ \\
\hline Reflections with $[\mathrm{I}>2 \sigma(\mathrm{I})]$ & 1669 \\
\hline Cell measurementreflections used & 1669 \\
\hline Weighting details & $\begin{array}{l}\mathrm{w}=1 /\left[\sigma^{2}\left(\mathrm{~F}_{\mathrm{o}}^{2}\right)+(0.0335 \mathrm{P})^{2}\right] \\
\text { where } \mathrm{P}=\left(\mathrm{F}_{\mathrm{o}}^{2}+2 \mathrm{~F}_{\mathrm{c}}^{2}\right) / 3\end{array}$ \\
\hline Data / restrains / parameters & $2582 / 0 / 253$ \\
\hline Goodness-of-fit on $\mathrm{F}^{2}$ & 1.002 \\
\hline Final $\mathrm{R}$ indices $[\mathrm{I}>2 \sigma(\mathrm{I})]$ & $\mathrm{R}_{1}=0.0288, \mathrm{wR}_{2}=0.0621$ \\
\hline $\mathrm{R}$ indices (all data) & $\mathrm{R}_{1}=0.0496, \mathrm{wR}_{2}=0.0645$ \\
\hline Largest difference peak and hole & 0.108 and $-0.102 \mathrm{e} \cdot \AA^{-3}$ \\
\hline
\end{tabular}

Table 2. Selected bond lengths $[\AA]]$ and angles $\left[^{\circ}\right]$ for $3 b$.

\begin{tabular}{cccc}
\hline Bond & Length value & Angle & Degree value \\
\hline $\mathrm{C}(4)-\mathrm{O}(3)$ & $1.2179(17)$ & $\mathrm{O}(3)-\mathrm{C}(4)-\mathrm{N}(3)$ & $120.20(16)$ \\
$\mathrm{N}(3)-\mathrm{C}(4)$ & $1.4000(19)$ & $\mathrm{C}(4)-\mathrm{N}(3)-\mathrm{C}(16)$ & $117.37(12)$ \\
$\mathrm{C}(2)-\mathrm{N}(3)$ & $1.3987(17)$ & $\mathrm{C}(2)-\mathrm{N}(3)-\mathrm{C}(16)$ & $120.95(12)$ \\
$\mathrm{N}(3)-\mathrm{C}(16)$ & $1.4473(19)$ & $\mathrm{N}(3)-\mathrm{C}(2)-\mathrm{C}(1)$ & $117.22(13)$ \\
$\mathrm{C}(2)-\mathrm{N}(1)$ & $1.2914(18)$ & $\mathrm{N}(1)-\mathrm{C}(2)-\mathrm{C}(1)$ & $119.36(13)$ \\
$\mathrm{C}(2)-\mathrm{C}(1)$ & $1.459(2)$ & $\mathrm{C}(18)-\mathrm{C}(17)-\mathrm{C}(3)$ & $122.36(13)$ \\
$\mathrm{C}(3)-\mathrm{C}(1)$ & $1.3142(19)$ & $\mathrm{N}(1)-\mathrm{C}(2)-\mathrm{N}(3)$ & $123.42(13)$ \\
$\mathrm{C}(3)-\mathrm{C}(17)$ & $1.459(2)$ & $\mathrm{C}(19)-\mathrm{C}(20)-\mathrm{N}(2)$ & $118.47(15)$ \\
$\mathrm{C}(20)-\mathrm{N}(2)$ & $1.4622(19)$ & $\mathrm{C}(21)-\mathrm{C}(20)-\mathrm{C}(19)$ & $122.13(13)$ \\
$\mathrm{N}(2)-\mathrm{O}(1)$ & $1.2186(17)$ & $\mathrm{C}(15)-\mathrm{C}(16)-\mathrm{N}(3)$ & $119.11(14)$ \\
\hline
\end{tabular}




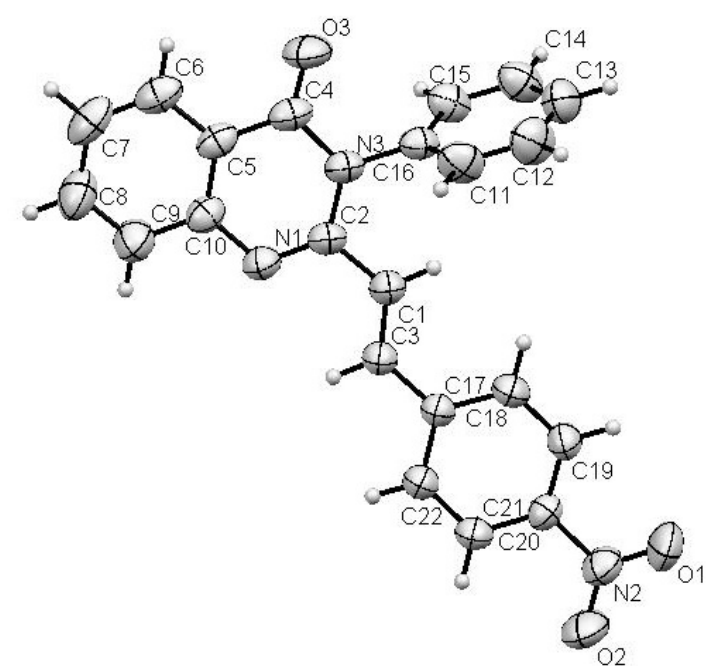

Figure 1. ORTEP plot $(50 \%)$ of molecular structure of $3 \mathrm{~b}$.

ects of substituents of different electronic nature we have selected 3-phenyl-trans-2-(heteryl)vinyl-3-quinazolin-4ones 4 and 5 bearing pyridin-2-yl and 2-thienyl fragments.

3-Phenyl-trans-2-[2-(pyridin-2-yl)vinyl]-3H-quinazolin-4-one $4 \mathbf{a}$ and the difluoro analog $\mathbf{4 b}$ have been obtained by condensation of 2-methylquinazolinones 1a,b with pyridin-2-carbaldehyde on heating in tetrahydrofuran in the presence of $\mathrm{ZnCl}_{2}$ and acetic anhydride for 5 hours in 61\% - 64\% yields (Scheme 2). The synthesis of unknown earlier 2-[(2-thiophen-2-yl)vinyl derivatives 5a, b was achieved by refluxing 1a,b with thiophen-2-carbaldehyde and sodium acetate in acetic acid for 12 - 36 hours in 36\% - 70\% yields. Structures of $\mathbf{4 a}, \mathbf{b}$ and $\mathbf{5 a}, \mathbf{b}$ were confirmed by the ${ }^{1} \mathrm{H}$ NMR and mass-spectra data.

The nitrogen-containing $\pi$-electrondeficient heterocycles, such as pyridines, quinolines, quinoxalines, appear to be potential candidates for ETL (electron-transporting layer) materials [19]. Therefore, incorporation of the pyridinyl unit at the position 3 in quinazolines can enhance electron transporting properties.

Novel trans-2-[2-(4-methoxyphenyl)vinyl]-3-(pyridin2-yl)-3 $H$-quinazolin-4-ones $\mathbf{7 a , b}$ were prepared by using quinazolinones $\mathbf{6 a , b}$ as the starting materials. 2-Methyl3-pyridinyl-3H-quinazolin-4-one 6a was reacted with 4-methoxybenzaldehyde in acetic acid in the presence of sodium acetate to give $\mathbf{7 a}$ in $47 \%$ yield. However, we failed to prepare $\mathbf{7 b}$ under similar reaction conditions in good or moderate yield. Compound $\mathbf{7 b}$ was obtained by condensation of difluoroquinazolinone $\mathbf{6 b}$ with 4-methoxybenzaldehyde on heating in tetrahydrofuran in the presence of $\mathrm{ZnCl}_{2}$ and acetic anhydride for 12 hours in $35 \%$ yield (Scheme 3). The structure of 3-pyridinylquinazolinones $\mathbf{7 a , b}$ was confirmed by the ${ }^{1} \mathrm{H}$ NMR and mass spectra. In the ${ }^{1} \mathrm{H}$ NMR spectra of $\mathbf{7 a}, \mathbf{b}$ four signals of protons of the pyridinyl fragment (as well as in the

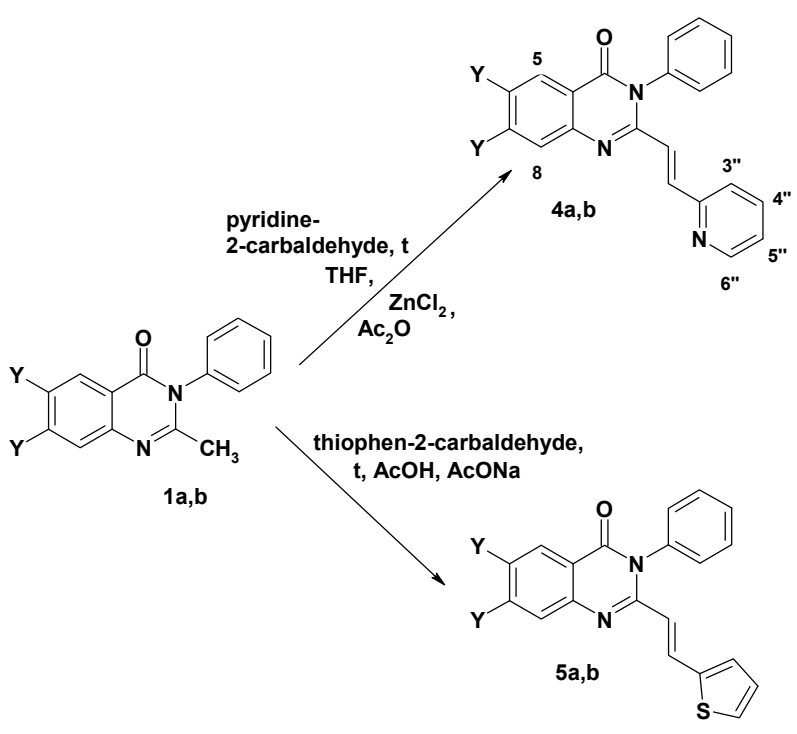

1, 4, 5: $\mathrm{Y}=\mathrm{H}(\mathbf{a}), \mathrm{F}(\mathbf{b})$

Scheme 2. Synthesis of trans-2-(heteryl)vinyl-3-phenyl-3Hquinazolin-4-ones 4 and 5.

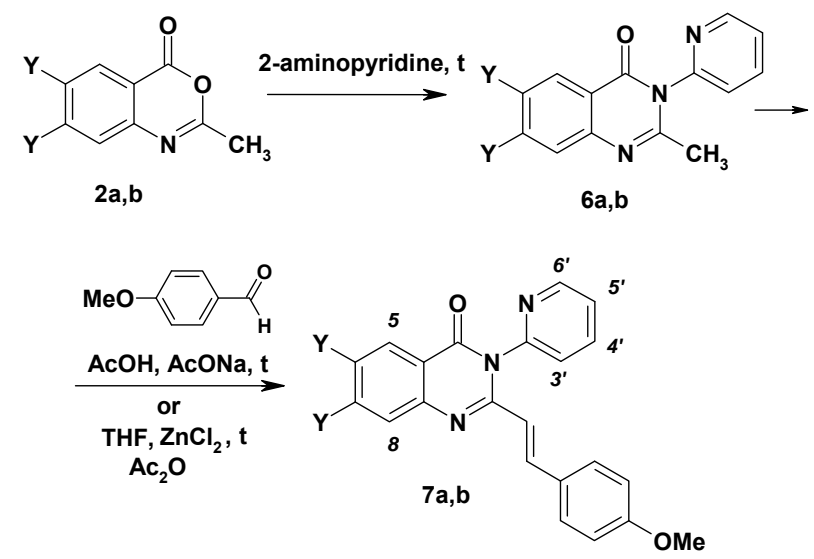

2, 6, 7: $\mathrm{Y}=\mathrm{H}(\mathbf{a}), \mathrm{F}(\mathbf{b})$

Scheme 3. Synthesis of trans-2-[2-(4-methoxyphenyl)vinyl]3-(pyridin-2-yl)-3H-quinazolin-4-ones 7.

spectra of the starting material 6), doublets of $\mathrm{CH}=\mathrm{CH}$ protons (at $5.92-5.95$ and $7.88-7.89$ ppm with ${ }^{3} J 15.3$ $15.4 \mathrm{~Hz}$ ), and the signals of the benzene ring and aryl substituents were observed.

3-Phenyl/pyridinyl-trans-2-(aryl/heteryl)vinyl-3Hquinazolin-4-ones 3-5, and 7 bearing the quinazolinium moiety as electron acceptor and various substituents in the styryl moiety have been obtained, and strusture effects on photophysical behavior of compounds have been studied. Values for maximal absorption and emission spectra, as well as the Stokes shifts for quinazolinones 35, 7 are collected in Table 3. Absorbtion spectra proved to have the longest wavelength band in $\mathrm{MeCN}$ ranging from 330 to $350 \mathrm{~nm}$. Being subjected to photo excitation, compounds 3-5 and 7 display photoluminescence in so- 
lution at room temperature. We investigated the dependence of an emission spectra on the nature of substituents attached to the styryl moiety.

Emission maximum of methoxyphenyl- and thienyl derivatives involving the fluorine atoms at 6 and 7 positions $(\mathbf{3 c}, \mathbf{5 b})$ is larger then one of non-fluorinated compounds 3a, 5a. Incorporation of fluorine atoms does not change the emission maximum for 2-pyridinylvinylderivatives (4b vs $\mathbf{4 a}$ ), and results in blue effect for nitrophenyl- and 3-pyridinyl derivatives (3d vs $\mathbf{3 b}$ and $\mathbf{7 b}$ vs 7a, Table 3). The emission maximum decreases in the following order: 4- $\mathrm{NO}_{2} \mathrm{C}_{6} \mathrm{H}_{4}>4-\mathrm{CH}_{3} \mathrm{OC}_{6} \mathrm{H}_{4}>$ thienyl $>$ pyridinyl both for fluorinated, and not fluorinated quinazolinones 3-5 (Table 3, Figure 2). Displacement of the phenyl group in position 3 of quinazolinone with the 2-pyridinyl unit leads to a large blue shift of the emission maxima (7b vs 3c) (Table 3, Figure 2). Fluorescence quantum yields proved to be rather small.

A low intensity of fluorescence of styrylderivatives 35,7 is in agreement with data for styrylquinolinium dyes [20]. According to the articles [21,22] the weak emission may be due to a competitive quenching through the trans-cis $\mathrm{C}=\mathrm{C}$ photo isomerization process. Rather low luminescence intensities for compounds 3-5 and 7 in solutions are also obliged to the $(E)-(Z)$-isomerization. In a frozen glass at $77 \mathrm{~K}$, conformational changes of styrylsubstituted systems are suppressed, and intensities of the emission are expected to get increased [17]. Spectra of absorption and emission of compounds 3-5 and 7 have been recorded in 2-methyltetrahydrofurane at $293 \mathrm{~K}$ and 77 K. It follows from Table 4 and Figure 3 that the emission spectra of quinazolinones 3-5 and $\mathbf{7}$ recorded at low temperature have a great difference from those at room temperature. Under a low temperature the intensity of luminescence is enhanced significantly (Table 4).

Thus, the tuning of the photophysical properties introducing substituents in styrylquinazolinones is very useful. Heterocyclic compounds based on quinazolinone scaffold proved to exhibit attractive properties in various aggregation states, and they appear to be promising for further study.

\section{Experimental Section}

\subsection{General}

All melting points were determined using a Stuart SMP3 Melting Point Apparatus in open capillary tubes. ${ }^{1} \mathrm{H}$ NMR spectra were recorded on a Bruker DRX 400 instrument $(400.13 \mathrm{MHz})$. Chemical shifts are given in ppm $(\delta)$ from the internal TMS standard. Mass spectra were obtained from a MicrOTOF-Q II mass spectral instrument (Bruker Daltonics, positive or negative APCI ion source, electrospray ionization). Acetonitrile (99\% purity), 2-methyltetrahydrofurane $(99 \%$, stab. with ca 150 - 400 ppm BHT) (Alfa Aesar, UK) was used at UV-

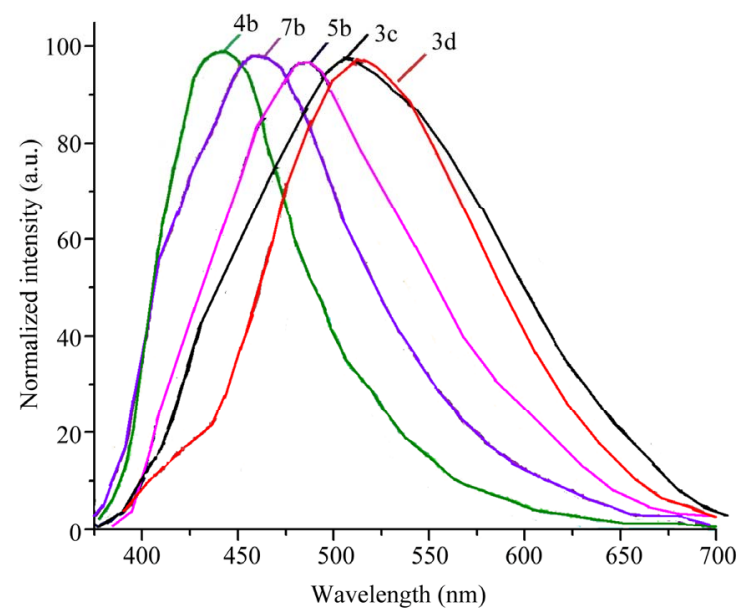

Figure 2. Emission spectra of difluoroquinazolinones 3c,d, $4 b, 5 b$, and $7 b$ in acetonitrile solution.

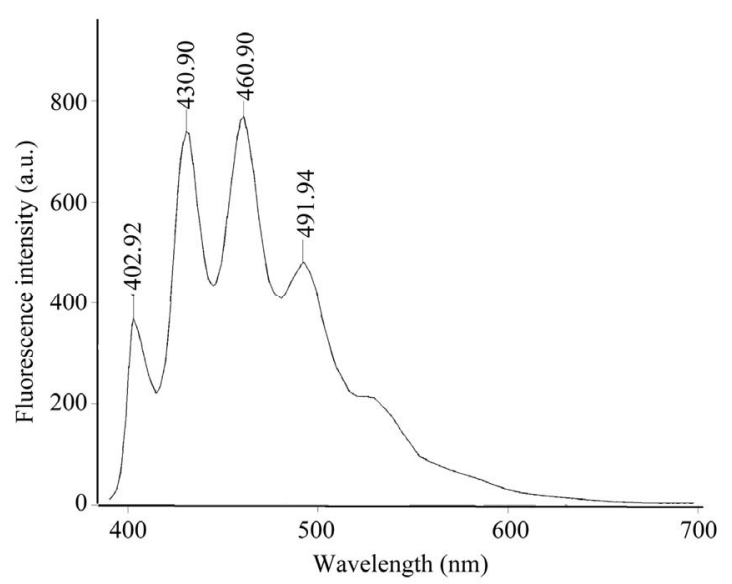

Figure 3. Emission spectra of 6,7-difluoro-2-[2-(pyridin-2yl)vinyl]-3-phenyl-3H-quinazolin-4-one $4 \mathrm{~b}$ at $\mathrm{T}=77 \mathrm{~K}$ in-2methyltetrahydrofurane.

Table 3. The absorbtion and fluorescence maxima of quinazolin-4-ones 3-5 and 7 in acetonitrile at $293 \mathrm{~K}$.<smiles>[Y]c1cc2nc(/C=C/C=[W])n(-c3ccccc3)c(=O)c2cc1[Y]</smiles>

\begin{tabular}{cccc}
\hline Compound & $\lambda_{\mathrm{a}}(\mathrm{nm})$ & $\lambda_{\mathrm{f}}(\mathrm{nm})$ & Stokes shift $(\mathrm{nm})$ \\
\hline $\mathbf{3 a}$ & 348 & 485 & 137 \\
$\mathbf{3 b}$ & 355 & 540 & 185 \\
$\mathbf{3 c}$ & 347 & 514 & 134 \\
$\mathbf{3 d}$ & 350 & 521 & 171 \\
$\mathbf{4 a}$ & 336 & 450 & 114 \\
$\mathbf{4 b}$ & 330 & 450 & 120 \\
$\mathbf{5 a}$ & 352 & 460 & 108 \\
$\mathbf{5 b}$ & 352 & 480 & 128 \\
$\mathbf{7 a}$ & 349 & 480 & 131 \\
$\mathbf{7 b}$ & 350 & 461 & 111 \\
\hline
\end{tabular}


Table 4. The absorbtion and fluorescence spectra of quinazolin-4-ones 3-5, 7 in 2-methyltetrahydrofuran at $293 \mathrm{~K}$ and $77 \mathrm{~K}$.

\begin{tabular}{cccc}
\hline Compound & $\lambda_{\mathrm{a}}(\mathrm{nm})$ & $\lambda_{\mathrm{f}}, \mathrm{nm}(\mathrm{I}, \mathrm{a} . \mathrm{u})$ at $293 \mathrm{~K}$ & $\lambda_{\mathrm{f}}, \mathrm{nm}(\mathrm{I}, \mathrm{a} . \mathrm{u})$ at $77 \mathrm{~K}$ \\
\hline $\mathbf{3 a}$ & 369 & $481(0.2)$ & $450(209), 481(209), 516(118), 551 \mathrm{sh}(47)$ \\
$\mathbf{3 b}$ & 396 & $522(2.2)$ & $522(298)$ \\
$\mathbf{3 c}$ & 388 & $480(4)$ & $420(342), 448(639), 480(569), 516(298), 560 \mathrm{sh}(103)$ \\
$\mathbf{3 d}$ & 396 & $474(3)$ & $441(91), 474(116), 509(94), 547 \mathrm{sh}(47)$ \\
$\mathbf{4 a}$ & 378 & $465(2)$ & $406(231), 435(451), 465(459), 498(289), 535 \mathrm{sh}(113)$ \\
$\mathbf{4 b}$ & 375 & $461(2.6)$ & $403(368), 431(738), 461(768), 492(481), 527 \mathrm{sh}(213)$ \\
$\mathbf{5 a}$ & 428 & $467(4)$ & $436(276), 467(611), 502(584), 539(344), 585 \mathrm{sh}(138)$ \\
$\mathbf{5 b}$ & 401 & $499(1)$ & $436(127), 465(268), 499(261), 534(162), 582 \mathrm{sh}(68)$ \\
$7 \mathbf{7}$ & 390 & $449(4)$ & $423(337), 449(658), 482(612), 518(341), 562 \mathrm{sh}(130)$ \\
$\mathbf{7 b}$ & 390 & $449(4)$ & $422(226), 449(417), 480(369), 198(520), 574(95)$ \\
\hline
\end{tabular}

spectroscopy grade. Absorption spectra were scanned on UV-2401 PC absorption spectrophotometer (Shimadzu, Japan) using a $1 \mathrm{~cm}$ quartz cell, concentration: 0.0001 $\mathrm{mmol} / \mathrm{ml}$ (acetonitrile). Emission spectra were recorded on a Cary Eclipse spectrofluorimeter (Varian, USA). The fluorescence of the acetonitrile solution at $\mathrm{T}=293 \mathrm{~K}$ was measured in $1 \mathrm{~cm}$ cuvette. Quantum yields $\left(\varphi_{\mathrm{f}}\right)$ were determined relative to quinine sulfate in $1 \mathrm{~N} \mathrm{H}_{2} \mathrm{SO}_{4}\left(\varphi_{\mathrm{f}}=\right.$ 0.546) [23]. The concentration was adjusted so that the absorbance of the solution would be lower than 0.1 . The excitation was performed at the $366 \mathrm{~nm}$. Low-temperature measurements were carried out in a liquid nitrogen cryostat OptistatDN (Oxford Instrument) in 2-methyltetrahydrofuran solution at $\mathrm{T}=293 \mathrm{~K}$ and $\mathrm{T}=77 \mathrm{~K}$.

All reactions were monitored by thin layer chromatography (TLC) on $0.2 \mathrm{~mm}$ silica gel F-254 (Merck) plates using light (254 and $365 \mathrm{~nm})$ for detection. Elemental analyses were performed at the Microanalytical Laboratory of the Postovsky Institute of Organic Synthesis.

$\mathrm{X}$-Ray analysis including data collection, cell refinement and data reduction was carried out with an Oxford Diffraction Xcalibur S CCD diffractometer using CrysAlisPro software package [24]. X-ray data collection was carried out with graphite monochromatized Mo-K $\alpha$ radiation $(\alpha=0.71073 \AA)$. A correction for absorption not performed. The structure was solved by direct methods using SHELXS-97 and refined by full-marix leastsquares procedure on $\mathrm{F}^{2}$ with SHELXL-97 [25]. Non-H atoms were refined anisotropically, hydrogen atoms were placed in idealized positions and were constrained to ride on their parent atoms. Summary of the crystal data and structure refinement parameters are presented in the Table 1. Crystallographic data have been deposit with Cambridge Crystallographic Data Center as supplementary publication no. CCDC 857036. Copies of data can be obtained free of charge via the Internet http://www.ccdc.cam.ac.uk, or on application to the director; CCDC; 12 Unin Road, Cambridge CB2 1EZ, UK; deposit@ccdc.cam.ac.uk.

Quinazolinone 1a was obtained by heating of 3,1benzoxazin-4-one with aniline in pyridine using the described method [26]. Fluorinated derivative 1b was reported [27]. Quinazolinone 6a was synthesized by heating of $\mathbf{2 a}$ with 2-aminopyridine in DMF by using the known procedure [28], fluorinated derivative $\mathbf{6 b}$ was reported [26]. Replacement of DMF as solvent with pyridine in the synthesis of $\mathbf{6 b}$ required increase in reaction time from 40 min to 4 hours; however it gave a better yield of the target product ( $85 \%$ instead of $68 \%$ ).

\subsection{General Procedure for Preparation of 3-Phenyl-(E)-2-[2-(pyridin-2-yl)vinyl]-3H- quinazolin-4-ones 4a,b}

To a solution of 2-methyl-3-phenyl-4H-quinazolin-4-one $1(1.1 \mathrm{mmol})$ in THF $(7 \mathrm{ml})$ acetic anhydride $(0.5 \mathrm{ml})$, pyridine-2-carbaldehyde $(0.28 \mathrm{~g}, 1.9 \mathrm{mmol})$ and $\mathrm{ZnCl}_{2}$ $(0.3 \mathrm{~g}, 1.65 \mathrm{mmol})$ were added. The mixture was refluxed for 6 hours, cooled to room temperature, the formed solid was filtered off, washed with cold water $(20 \mathrm{ml})$ and crystallized from acetontrile to afford the corresponding quinazolinone derivatives $\mathbf{4 a , b}$.

3-Phenyl-(E)-2-[2-(pyridin-2-yl)vinyl]-3H-quinazolin4-one 4a:

Yellow crystals; m.p. $248-250^{\circ} \mathrm{C}$; yield $(61 \%) .{ }^{1} \mathrm{H}$ NMR (DMSO-d $\left.)_{6}\right): \delta=6.91\left(\mathrm{~d},{ }^{3} J 15.0 \mathrm{~Hz}, 1 \mathrm{H}, \mathrm{CH}=\right)$, 7.24 (m, 1H, H-5”), 7.37 (m, 2H, H-3', H-5'), 7.43 (m, 1H, H-4'), 7.50 (m, 1H, H-8), 7.6-7.7 (m, 3H, H-3', H-2', H-6'), 7.72 - 7.76 (m, 2H, H-7, H-6), 7.83 (m, 1H, H-4"), $7.89\left(\mathrm{~d},{ }^{3} \mathrm{~J} 15.0 \mathrm{~Hz}, 1 \mathrm{H}, \mathrm{CH}=\right), 8.15(\mathrm{~m}, 1 \mathrm{H}, \mathrm{H}-5), 8.46$ (m, 1H, H-6"). MS (ES $\left.{ }^{+}\right): \mathrm{m} / \mathrm{z}(\%)=326[\mathrm{M}+\mathrm{H}]^{+} 100$. 
Anal. for $\mathrm{C}_{21} \mathrm{H}_{15} \mathrm{~N}_{3} \mathrm{O}$ : calcd. C, 77.52; $\mathrm{H}, 4.65 ; \mathrm{N}, 12.91$. found $\mathrm{C}, 77.58 ; \mathrm{H}, 4.71 ; \mathrm{N}, 12.85$.

6,7-Difluoro-3-phenyl-(E)-2-[2-(pyridin-2-yl)-vinyl]-3Hquinazolin-4-one $4 b$ :

Yellow crystals; m.p. $270^{\circ} \mathrm{C}-272^{\circ} \mathrm{C}$; yield $(64 \%) .{ }^{1} \mathrm{H}$ NMR (DMSO-d $\left.\mathrm{d}_{6}\right): \delta=6.91\left(\mathrm{~d},{ }^{3} J 15.0 \mathrm{~Hz}, 1 \mathrm{H}, \mathrm{CH}=\right)$, 7.32 (ddd, ${ }^{3} J 7.8,{ }^{3} J 4.5,{ }^{4} J 0.7 \mathrm{~Hz}, 1 \mathrm{H}, \mathrm{H}-5$ "), 7.48 (dd, ${ }^{3} J 8.1,{ }^{4} J 1.9 \mathrm{~Hz}, 2 \mathrm{H}, \mathrm{H}-3$ ', H-5'), 7.55 (m, 1H, H-4'), 7.6-7.7 (m, 3H, H-3', H-2', H-6'), 7.81 (td, ${ }^{3} J 7.8,{ }^{4} J 1.8$ $\mathrm{Hz}, 1 \mathrm{H}, \mathrm{H}-4$ "), $7.86\left(\mathrm{dd},{ }^{3} J_{H-F} 11.3,{ }^{4} J_{H-F} 7.1 \mathrm{~Hz}, 1 \mathrm{H}\right.$, $\mathrm{H}-8), 7.90\left(\mathrm{~d},{ }^{3} \mathrm{~J} 15.0 \mathrm{~Hz}, 1 \mathrm{H}, \mathrm{CH}=\right), 8.07\left(\mathrm{dd},{ }^{3} J_{H-F} 10.2\right.$, $\left.{ }^{4} J_{H-F} 8.9 \mathrm{~Hz}, 1 \mathrm{H}, \mathrm{H}-5\right), 8.49\left(\mathrm{dd},{ }^{3} J 4.5,{ }^{4} J 1.3 \mathrm{~Hz}, 1 \mathrm{H}\right.$, H-6"). MS $\left(\mathrm{ES}^{+}\right): m / z(\%)=362(\mathrm{M}+\mathrm{H})^{+} 100$. Anal. for $\mathrm{C}_{21} \mathrm{H}_{13} \mathrm{~F}_{2} \mathrm{~N}_{3} \mathrm{O}$ : calcd. C, $68.80 ; \mathrm{H}, 3.63 ; \mathrm{N}, 10.52$. found C, 68.86; H, 3.70; N, 10.48 .

\subsection{General Procedure for Preparation of 3-Phenyl-(E)-2-[2-(2-thiophen-2-yl)vinyl]- $3 \mathrm{H}$-quinazolin-4-ones 5a,b}

To a solution of 2-methylquinazolinone $\mathbf{1}(0.85 \mathrm{mmol})$ in glacial acetic acid $(4 \mathrm{ml})$ anhydrous sodium acetate $(0.05$ g) and thiophen-2-carbaldehyde $(0.2 \mathrm{ml}, 1.8 \mathrm{mmol})$ were added. The mixture was refluxed for $12 \mathrm{~h}$ (for preparation of 5a) or 36 hours (for preparation of $\mathbf{5 b}$ ), then cooled and the solvent was removed in vacuo, the residual solid was recrystallized from acetonitrile.

(E)-3-Phenyl-2-[(2-thiophen-2-yl)vinyl]-3H-quinazoli n-4-one $5 a$ :

Yellow crystals; m.p. $272^{\circ} \mathrm{C}-274^{\circ} \mathrm{C}$; yield (36\%). ${ }^{1} \mathrm{H}$ NMR (DMSO-d $\left.\mathrm{d}_{6}\right): \delta=6.02\left(\mathrm{~d},{ }^{3} J 15.2 \mathrm{~Hz}, 1 \mathrm{H}, \mathrm{CH}=\right)$, 7.02 (dd, ${ }^{3} J 5.3,3.4 \mathrm{~Hz}, 1 \mathrm{H}, \mathrm{H}-4$ "), 7.26 (d, ${ }^{3} J 3.4 \mathrm{~Hz}, 1 \mathrm{H}$, H-5”), 7.35 (m, 2H, H-3', H-5'), 7.43 (d, ${ }^{3} J 5.3 \mathrm{~Hz}, 1 \mathrm{H}$, H-3"), 7.47 (m, 1H, H-6), 7.61 (m, 3H, H-2', H-4', H-6'), $7.69(\mathrm{~m}, 1 \mathrm{H}, \mathrm{H}-8), 7.81(\mathrm{~m}, 1 \mathrm{H}, \mathrm{H}-7), 8.04\left(\mathrm{~d},{ }^{3} \mathrm{~J} 15.2 \mathrm{~Hz}\right.$, $1 \mathrm{H}, \mathrm{CH}=), 8.12(\mathrm{~m}, 1 \mathrm{H}, \mathrm{H}-5)$. MS $\left(\mathrm{ES}^{+}\right): m / z(\%)=331$ $(\mathrm{M}+\mathrm{H})^{+}$100. Anal. for $\mathrm{C}_{20} \mathrm{H}_{14} \mathrm{~N}_{2} \mathrm{OS}$ : calcd. C, 72.70; H, 4.27; N, 8.48. found: C, 72.67; H, 4.23; N, 8.51.

6,7-Difluoro-3-phenyl-(E)-2-[(2-thiophen-2-yl)vinyl]-3 $H$-quinazolin-4-one $5 b$ :

Yellow crystals; m.p. $230^{\circ} \mathrm{C}-232^{\circ} \mathrm{C}$; yield $(70 \%) .{ }^{1} \mathrm{H}$ NMR (DMSO-d $\left.\mathrm{d}_{6}\right): \delta 6.00\left(\mathrm{~d},{ }^{3} J 15.2 \mathrm{~Hz}, 1 \mathrm{H}, \mathrm{CH}=\right), 7.04$ (dd, ${ }^{3} J 5.0,3.6 \mathrm{~Hz}, 1 \mathrm{H}, \mathrm{H}-4$ ") 7.29 (d, ${ }^{3} J 3.6 \mathrm{~Hz}, 1 \mathrm{H}$, H-5”), 7.37 (m, 2H, H-3', H-5'), 7.47 (d, ${ }^{3} J 5.0 \mathrm{~Hz}, 1 \mathrm{H}$, H-3"), 7.59 - 7.66 (m, 4H, H-2', H-4', H-6', H-8), 7.97 (dd, $\left.{ }^{3} J_{H-F} 10.1,{ }^{4} J_{H-F} 8.8 \mathrm{~Hz}, 1 \mathrm{H}, \mathrm{H}-5\right), 8.04\left(\mathrm{~d},{ }^{3} J 15.2 \mathrm{~Hz}\right.$, $1 \mathrm{H}, \mathrm{CH}=)$. MS $\left(\mathrm{ES}^{+}\right): m / z(\%)=367(\mathrm{M}+\mathrm{H})^{+} 100$. Anal. for $\mathrm{C}_{20} \mathrm{H}_{12} \mathrm{~F}_{2} \mathrm{~N}_{2} \mathrm{OS}$ : calcd. C, 65.56; $\mathrm{H}, 3.30 ; \mathrm{N}, 7.65$. found: $\mathrm{C}, 65.54 ; \mathrm{H}, 3.27 ; \mathrm{N}, 7.68$.

\subsection{Preparation of (E)-2-[2-(4-Methoxyphenyl)- vinyl]-3-(pyridin-2-yl)-3H-quinazolin-4-ones $7 \mathbf{a}, \mathbf{b}$}

(E)-2-[2-(4-methoxyphenyl)vinyl]-3-(pyridin-2-yl)-3H-qui- nazolin-4-one 7a:

To a solution of 2-methylquinazolinone $\mathbf{6 a}(0.3 \mathrm{~g}, 1.26$ $\mathrm{mmol})$ in glacial acetic acid $(5 \mathrm{ml})$ anhydrous sodium acetate $(0.07 \mathrm{~g})$ and $p$-methoxybenzaldehyde $(0.4 \mathrm{ml}, 4.4$ $\mathrm{mmol}$ ) were added. The mixture was refluxed for 6 hours, then cooled and the solvent was removed in vacuo, the residual solid was recrystallized from ethanol.

Yellow crystals; m.p. $205^{\circ} \mathrm{C}-207^{\circ} \mathrm{C}$; yield $(47 \%) .{ }^{1} \mathrm{H}$ NMR (DMSO-d $\left.\mathrm{d}_{6}\right): \delta=3.78\left(\mathrm{~s}, 3 \mathrm{H}, \mathrm{OCH}_{3}\right), 5.95(\mathrm{~d}, 1 \mathrm{H}$, $\left.{ }^{3} J 15.4 \mathrm{~Hz}, \mathrm{CH}=\right), 6.85\left(\mathrm{~d},{ }^{3} J 8.8 \mathrm{~Hz}, 2 \mathrm{H}, \mathrm{H}-3\right.$ ', H-5'), 7.27 (d, ${ }^{3} J 8.8 \mathrm{~Hz}, 2 \mathrm{H}, \mathrm{H}-2$ ', H-6'), 7.47 (td, ${ }^{3} J 7.9,4 J$ $1.1 \mathrm{~Hz}, 1 \mathrm{H}, \mathrm{H}-6), 7.57$ (d, $\left.{ }^{3} J 7.9 \mathrm{~Hz}, 1 \mathrm{H}, \mathrm{H}-8\right), 7.63$ (ddd, ${ }^{3} J 7.5,{ }^{3} J 4.8,{ }^{4} J 0.9 \mathrm{~Hz}, 1 \mathrm{H}, \mathrm{H}-5$ ") $), 7.71\left(\mathrm{~d},{ }^{3} J 7.9 \mathrm{~Hz}, 1 \mathrm{H}\right.$, H-5), $7.81\left(\mathrm{td},{ }^{3} J 6.9,{ }^{4} J 1.5 \mathrm{~Hz}, 1 \mathrm{H}, \mathrm{H}-7\right), 7.89\left(\mathrm{~d},{ }^{3} J\right.$ $15.4 \mathrm{~Hz}, 1 \mathrm{H}, \mathrm{CH}=), 8.11\left(\mathrm{td},{ }^{3} J 7.8,{ }^{4} J 1.9 \mathrm{~Hz}, 1 \mathrm{H}, \mathrm{H}-4 "\right)$, 8.14 (dd, ${ }^{3} J 7.8,{ }^{4} J 1.3 \mathrm{~Hz}, 1 \mathrm{H}, \mathrm{H}-3$ "), 8.71 (dd, ${ }^{3} J 4.8,{ }^{4} J$ $1.1 \mathrm{~Hz}, 1 \mathrm{H}, \mathrm{H}-6 ") . \mathrm{MS}\left(\mathrm{ES}^{+}\right): m / z(\%)=356(\mathrm{M}+\mathrm{H})^{+}$ 100. Anal. for $\mathrm{C}_{22} \mathrm{H}_{17} \mathrm{~N}_{3} \mathrm{O}_{2}$ : calcd. C, 74.35; H, 4.82; N, 11.82. found: $\mathrm{C}, 74.36 ; \mathrm{H}, 4.85 ; \mathrm{N}, 11.78$.

6,7-Difluoro-(E)-2-[2-(4-methoxyphenyl)vinyl]-3(pyridin-2-yl)-3H-quinazolin-4-one $7 b$ :

To a solution of 2-methylquinazolinone $6 \mathbf{b}(0.3 \mathrm{~g}, 1.09$ mmol $)$ in THF $(10 \mathrm{ml})$ acetic anhydride $(0.3 \mathrm{ml}), p$-methoxybenzaldehyde $(0.4 \mathrm{ml}, 2.9 \mathrm{mmol})$ and $\mathrm{ZnCl}_{2}(0.3 \mathrm{~g}$, $1.65 \mathrm{mmol}$ ) were added. The mixture was refluxed for 12 hours, cooled to room temperature and the solvent was removed in vacuo, the residual solid was recrystallized from ethanol.

Colorless crystals; m.p. $203^{\circ} \mathrm{C}-205^{\circ} \mathrm{C}$; yield $(35 \%)$. ${ }^{1} \mathrm{H}$ NMR (DMSO-d $\left.\mathrm{d}_{6}\right): \delta 3.78\left(\mathrm{~s}, 3 \mathrm{H}, \mathrm{OCH}_{3}\right), 5.92\left(\mathrm{~d},{ }^{3} \mathrm{~J}\right.$ $15.3 \mathrm{~Hz}, 1 \mathrm{H}, \mathrm{CH}=), 6.85$ (d, ${ }^{3} J 8.6,2 \mathrm{H}, \mathrm{H}-3^{\prime}, \mathrm{H}-5$ '), 7.26 (d, ${ }^{3} J 8.6,2 \mathrm{H}, \mathrm{H}-2^{\prime}, \mathrm{H}-6$ '), 7.58 (d, $\left.{ }^{3} J 8.2 \mathrm{~Hz}, 1 \mathrm{H}, \mathrm{H}-3^{\prime \prime}\right)$, 7.60 - 7.70 (m, 2H, H-5", H-5), 7.88 (d, ${ }^{3} J 15.3 \mathrm{~Hz}, 1 \mathrm{H}$, $\mathrm{CH}=), 7.97\left(\mathrm{t},{ }^{3} J 9.4 \mathrm{~Hz}, 1 \mathrm{H}, \mathrm{H}-8\right), 8.12\left(\mathrm{td},{ }^{3} J 7.6,{ }^{4} J 1.4\right.$ $\mathrm{Hz}, 1 \mathrm{H}, \mathrm{H}-4$ "), 8.71 (d, ${ }^{3} \mathrm{~J} 3.7 \mathrm{~Hz}, 1 \mathrm{H}, \mathrm{H}-6$ "). $\mathrm{MS}^{+}\left(\mathrm{ES}^{+}\right)$: $m / z(\%)=392(\mathrm{M}+\mathrm{H})^{+}$100. Anal. for $\mathrm{C}_{22} \mathrm{H}_{15} \mathrm{~F}_{2} \mathrm{~N}_{3} \mathrm{O}_{2}$ : calcd. C, 67.52; H, 3.86; N, 10.74. found: $\mathrm{C}, 67.48 ; \mathrm{H}$, $3.83 ; \mathrm{N}, 10.79$.

\section{Acknowledgements}

This work was supported by the Russian Foundation for Basic Research (grant 11-03-00718), the Grant of the Leading Scientific Schools NSh-65261.2010.3, and also by the State Contract GK-02.740.11.0260.

\section{REFERENCES}

[1] A. P. deSilva, H. Q. Gunarantne, T. Gunnlaugsson, A. J. M. Huxley, C. P. McCoy, J. T. Rademacher and T. E. Rice, "Signaling Recognition Events with Fluorescent Sensors and Switches," Chemical Reviews, Vol. 97, No. 5, 1997, pp. 1515-1566. doi:10.1021/cr960386p

[2] S. A. Haroutounian and J. A. Katzenellenbogen, "4-Hydroxystyryldiazines: Synthesis and Fluorescence Properties," 
Tetrahedron, Vol. 51, No. 6, 1995, pp. 1585-1598. doi:10.1016/0040-4020(94)01050-A

[3] P. H. Bong, H. J. Kim, K. H. Chae, S. C. Shin, N. Nakashima and K. Yoshihara, "Photochemical Trans-cis Isomerization of 1,2-Bis(heteroaryl)ethylenes: 1,2-Bis(py-razinyl)ethylene," Journal of the American Chemical Society, Vol. 108, No. 5, 1986, pp. 1006-1014. doi:10.1021/ja00265a027

[4] T. L. Fevig, J. E. Lloyd, J. A. Zablocki and J. A. Katzenellenbogen, "Preparation, Receptor Binding, and Fluorescence Properties of Hexestrol Fluorophore Conjugates: Evaluation of Site of Attachment, Fluorophore Structure, and Fluorophore-Ligand Spacing," Journal of Medicinal Chemistry, Vol. 30, No. 1, 1987, pp. 156-165. doi:10.1021/jm00384a026

[5] B. R. Kim, S. D. Cho, H. G. Lee, H. S. Yim, M. J. Kim, J. Hwang, S. E. Park, J. J. Kim, K. J. Jung and Y. J. Yoon, "Substituent-Dependence of Photophysical Properties of Trans-2-Styrylpyridazin-3-(2H)-ones," Journal of Heterocyclic Chemistry, Vol. 46, No. 4, 2009, pp. 691-701. doi:10.1002/jhet.137

[6] K. M. K. Swamy, M. S. Park, S. J. Han, S. K. Kim, J. H. Kim, C. Lee, H. Bang, Y. Kim, S. J. Kim and J. Yoon, "New Pyrrolopyridazine Derivatives as Blue Organic Luminophors," Tetrahedron, Vol. 61, No. 43, 2005, pp. 10227-10234. doi:10.1016/j.tet.2005.08.038

[7] S. Achelle, I. Nouira, B. Pfaffinger, Y. Ramondenc, N. Ple and J. Rodriguez-Lopez, "V-Shaped 4,6-Bis-(arylvinyl)-pyrimidine Oligomers: Synthesis and Optical Properties," The Journal of Organic Chemistry, Vol. 74, No. 10, 2009, pp. 3711-3717. doi:10.1021/jo900107u

[8] S. M. Bakalova, A. G. Santos, I. Timcheva, J. Kaneti, I. L. Filipova, G. M. Dobrikov and V. D. Dimitrov, "Electronic Absorption and Emission Spectra and Computational Studies of Some 2-Aryl, 2-Styryl, and 2-(4-Aryl)butadienyl Quinazolin-4-ones," Journal of Molecular Structure (Theochem), Vol. 710, 2004, pp. 229-234. doi:10.1016/j.theochem.2004.07.037

[9] B. Bachowska and G. Matusiak, "Synthesis of a New Conjugated 2,2'-(1,4-Phenylenedivinylene)bis-quinoxaline and a Series of Styryl Derivatives of Quinoxaline and Quinoline as Promising Electro- and Photoluminescent Materials," Chemistry of Heterocyclic Compounds, Vol. 45, No. 1, 2009, pp. 80-84. doi:10.1007/s10593-009-0229-3

[10] I. N. Kang, H. K. Shim and T. Zyung, "Yellow- LightEmitting Fluorine-Substituted PPV Derivative," Chemistry of Materials, Vol. 9, No. 3, 1997, pp. 746-749. doi: $10.1021 / \mathrm{cm} 960455 \mathrm{~g}$

[11] R. M. Gurge, A. M. Sarker, P. M. Lahti, B. Hu and F. E. Karasz, "Light Emitting Properties of Fluorine-Substituted Poly(1,4-phenylene vinylenes)," Macromolecules, Vol. 30, No. 26, 1997, pp. 8286-8292. doi:10.1021/ma970693c

[12] T. V. Trashakhova, E. V. Nosova, M. S. Valova, P. A. Slepukhin, G. N. Lipunova and V. N. Charushin, "Synthesis and Photophysical Properties of 2-Styrylquinazolin-4-ones," Russian Journal of Organic Chemistry, Vol. 47, No. 5, 2011, pp. 753-761. doi:10.1134/S1070428011050150

[13] F. Liang, J. Chen, Y. Cheng, L. Wang, D. Ma, X. Jing and F. Wang, "Synthesis, Characterization, PhotolumiNescent and Electroluminescent Properties of New Conjugated 2,2'-(Arylenedivinylene)bis-8-substituted Quinolines," Journal of Materials Chemistry, Vol. 13, No. 6, 2003, pp. 1392-1399. doi:10.1039/b210408c

[14] C. C. Chen, K. Pan, S. L. Wang and T. I. Ho, "Styrylthiophene-Amine Exciplexes," Journal of Luminescence, Vol. 71, No. 4, 1997, pp. 321-328. doi:10.1016/S0022-2313(97)00092-6

[15] S. L. Wang and T. I. Ho, "Substituent Effects on Intramolecular Charge-Transfer Behaviour of Styrylheterocycles," Journal of Photochemistry and Photobiology. A: Chemistry, Vol. 135, No. 2-3, 2000, pp. 119-126. doi:10.1016/S1010-6030(00)00289-6

[16] O. K. Kim, A. Fort, M. Barzoukas, M. Blanchard-Desee and J. M. Lehn, "Nonlinear Optical Chromophores Containing Dithienothiophene as a New Type of Electron Relay," Journal of Materials Chemistry, Vol. 9, 1999, pp. 2227-2232. doi:10.1039/a902297j

[17] F. Würthner, F. Effenberger, R. Wortmann and P. Krämer, "Second-Order Polarizability of Donor-Acceptor Substituted Oligothiophenes: Substituent Variation and Conjugation Length Dependence," Chemical Physics, Vol. 173, No. 2, 1993, pp. 305-314. doi:10.1016/0301-0104(93)80147-2

[18] G. M. Xia, P. Lu, X. G. Xu and G. B. Xu, "Linear and Nonlinear Luminescence Properties of Bithiophene Based Materials," Optical Materials, Vol. 27, No. 1, 2004, pp. 109-113. doi:10.1016/j.optmat.2004.02.022

[19] M. Thelakkat and H. W. Schmidt, "Low Molecular Weight and Polymeric Heterocyclics as Electron Transport/Hole-Blocking Materials in Organic Light-Emitting Diodes," Polymers for Advanced Technologies, Vol. 9, No. 7, 1998, pp. 429-442. doi:10.1002/(SICI)1099-1581(199807)9:7<429::AID-PA T798>3.0.CO;2-E

[20] B. Jedrzejewska, M. Pietrzak and J. Paczkowski, "Solvent Effects on the Spectroscopic Properties of Styrylquinolinium Dyes Series," Journal of Fluorescence, Vol. 20, No. 1, 2010, pp. 73-86. doi:10.1007/s10895-009-0524-5

[21] W. A. E. Omar and O. E. O. Hormi, "Synthesis of 4-(2-Arylvinyl)-8-hydroxyquinolines via Anhydrous Heck Coupling Reaction and the PL Properties of Their Al Complexes," Tetrahedron, Vol. 65, No. 22, 2009, pp. 4422-4428. doi:10.1016/j.tet.2009.03.028

[22] B. Yin, F. Niemeyer, J. A. G. Williams, J. Jiang, A. Boucekkine, L. Toupet, H. L. Bozec and V. Guerchais, "Synthesis, Structure, and Photophysical Properties of Luminescent Platinum(II) Complexes Containing Cyclometalated 4-Styryl-Functionalized 2-Phenylpyridine Ligands," Inorganic Chemistry, Vol. 45, No. 21, 2006, pp. 8584-8596. doi:10.1021/ic0607282

[23] W. H. Melhuish, "Quantum Efficiencies of Fluorescence of Organic Substances: Effect of Solvent Concentration of the Fluorescent Solute," The Journal of Physical Chemistry, Vol. 65, No. 2, 1961, pp. 229-235. doi:10.1021/j100820a009

[24] Oxford Diffraction, "CrysAlysPro (Version 171.31.8) and 
CrysAlysRed (Version 1.171.31.8)," Oxford Diffraction Ltd., Abingdon, 2007.

[25] G. M. Sheldrick. "A Short History of SHELX," Acta Crystallographica, Section A, Vol. 64, No. 1, 2008, pp. 112-122. doi:10.1107/S0108767307043930

[26] J. A. Chong, C. Fander, G. R. Larsen, W. C. Lumma, M. M. Moran, A. Ripka, D. J. Underwood, M. Weigele and X. Zhen, "Compounds for Modulating TRPV3 Function," Chemical Abstracts, Vol. 147, 2007, Article ID: 422361f.

[27] A. A. Laeva, E. V. Nosova, A. V. Golovchenko, N. Yu.
Adonin, V. N. Parmon, G. N. Lipunova and V. N. Charushin, "Fluorine-Containing Heterocycles: XIX. Synthesis of Fluorine-Containing Quinazolin-4-ones from 3,1Benzoxazin-4-ones," Russian Journal of Organic Chemistry, Vol. 45, No. 6, 2009, pp. 913-920. doi:10.1134/S1070428009060190

[28] B. Dash, E. K. Dora and C. S. Panda, "Synthesis of Some New 2-Aryl-3-Hetaryl-4(3H)Quinazolones," Journal of the Indian Chemical Society, Vol. 57, No. 8, 1980, pp. 835-836. 